that the stimulation is unaffected by actinomycin, which has reduced the incorporation of orotic acid into nucleic acid to 5-10 per cent of the control values. The results presented here do not enable us to report any effect of growth hormone on nucleic acid synthesis, although experiments designed to study this more closely may reveal such effects.

During the writing of this communication Goodman ${ }^{18}$ reported that Knobil has also evidenee that the action of growth hormone in stimulating protein biosynthesis still occurs when the production of new nucleic acid in the muscle cell is inhibited.

We thank Dr. A. Stockell Hartree for purified human growth hormone, Miss M. B. Thomes for the hypophysectomies and Mr. D. C. Gardiner for general assistance.

T. E. Martin

F. G. YOUNG

Department of Biochemistry,

University of Cambridge.

' Park, C. R., Brown, D. H., Cornblath, M., Daughaday, W. H., and Krahl, M.

2 Ottaway, J. H., Biochim. Biophys. Acta, 11, 443 (1953).

Manchester, K. L., and Young, F. G., J. Endocrinol., 18, 381 (1959).

- Kostyo, J. L., and Knobil, E., Endocrinology, 65, 525 (1959).

${ }^{5}$ Manchester, K. L., and Wallis, M., Nature, 200, 888 (1963).

- Kostyo, J. L., Hotchkiss, J., and Knobil, E., Srience, 130, 1653 (1959).

${ }^{7}$ Kostyo, J. L., Endocrinology, 75, 113 (1964).

${ }^{8}$ Manchester, K. L., and Young, F. G., Vit. Horm., 19, 95 (1961).

- Eboue-Bonis, D., Chambaut, A. M., Volfin, P., and Clauser, H., Nature, 199, 1183 (1963)

${ }^{10}$ Franklin, R. M., Biochim. Biophys. Acta, 72, 555 (1963).

${ }^{11}$ Huggett, A. St. G., and Nixon, D. A., Biochem. J., 66, 12P (1957).

${ }^{12}$ Manchester, K. L., Biochem. J., 81, 135 (1961).

13 Wool, I. G., Biochim. Biophys. Acta, 68, 28 (1963).

'1" Wool, I. G., and Munro, A. J., Proc. U.S. Nat. Acad. Sei., 50, 918 (1963)

${ }^{15}$ Brenner, D., Jacob, F., and Meselson, M., Nature, 196, 576 (1961).

14 Goodman, H. M., Endocrinology, 76, 1134 (1965).

\section{Long-spacing Segments from Renatured al Sub-units of Collagen}

THF mammalian collagen molecule is thought to be composed of two $\alpha 1$ and one $\alpha 2$ peptide chains. Alpha 1 and $\alpha 2$ have approximately the same molecular weight but differ in their amino-acid composition ${ }^{1}$. A mixture of $\alpha \mathrm{I}$ and $\alpha 2$ in the ratio of $2: 1$ (produced by the denaturation of neutral salt-soluble rat skin collagen) re-forms, under certain conditions suitable for renaturation, as much as 50 per cent of the rod-like collagen molecules ${ }^{2}$. It is of interest to learn whether the triple helix of the collagen molecule can also be formed from three $\alpha 1$ chains. Recent ly, Piez and Carrillo ${ }^{3}$ have investigated the renaturation of the isolated sub-units $\left(\alpha 1, \alpha 2\right.$, and $\left.\beta_{12}\right)$ of collagen at $15^{\circ}$. According to our experience these conditions are not optimal for the formation of the triple helix ${ }^{4}$.

We isolated the $\alpha 1$ component from neutral salt-soluble calf skin collagen according to the method of Piez et al. ${ }^{1}$. Its homogeneity was checked by means of ultracentrifugation and starch-gel electrophoresis. Renuturation was achieved by incubating at a collagen concentration of $2 \cdot 6$ $\mathrm{mg} / \mathrm{ml}$. for $100 \mathrm{~h}$ at $22^{\circ}$ in $0.25 \mathrm{M}$ sodium citrate buffer, $p \mathrm{H} 3 \cdot 7$. The denaturation curve of the renatured solution gave a value of $30^{\circ}$ for $T_{m}$ (defined according to $\mathrm{v}$. Hippel et $a l .5$ ). Renatured acid-soluble collagen from calf skin has a $T_{m}$ of $33^{\circ}$ after renaturation under identical conditions.

When examined in the ultracentrifuge the renatured material showed, in addition to $\alpha 1$, a second, slower sedimenting peak which, during the course of the renaturation, grew at the expense of the $\alpha 1$ peak. Following the addition of pepsin (weight ratio of collagen: enzyme of 10:1; temp., $25^{\circ}$ ) the $\alpha 1$ component disappeared while the slower, pepsin-resistant peak, although not quite so sharp as the native molecule (Fig. 1), sedimented at approximately the same rate.

It was possible to produce long-spacing segments (Fig. 2) from the pepsin-resistant material, which accounted for

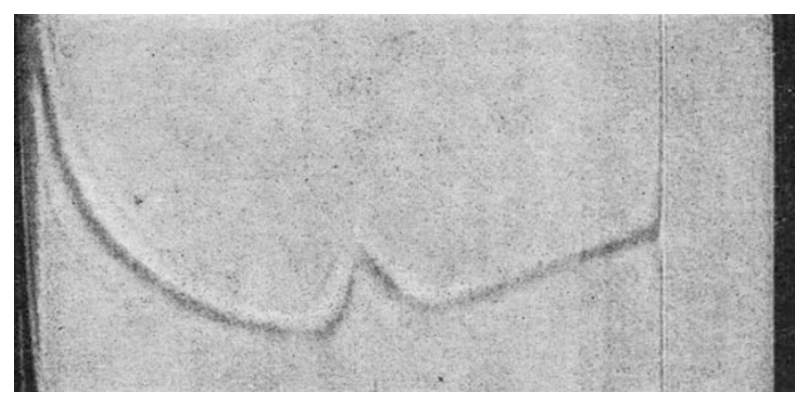

Fig. 1. Sedimentation diagram of renatured $\alpha 1$ after $18-\mathrm{h}$ pepsin treatment; concentration prior to pepsin addition $2.6 \mathrm{mg}$ collagen $/ \mathrm{ml}$. in $0.25 \mathrm{M}$ citrate buffer, $p H 3.7$; temp., $22^{\circ} ; 59,000$ r.p.m.; phase angle, $66^{\circ} ;$ photographed after $150 \mathrm{~min}$

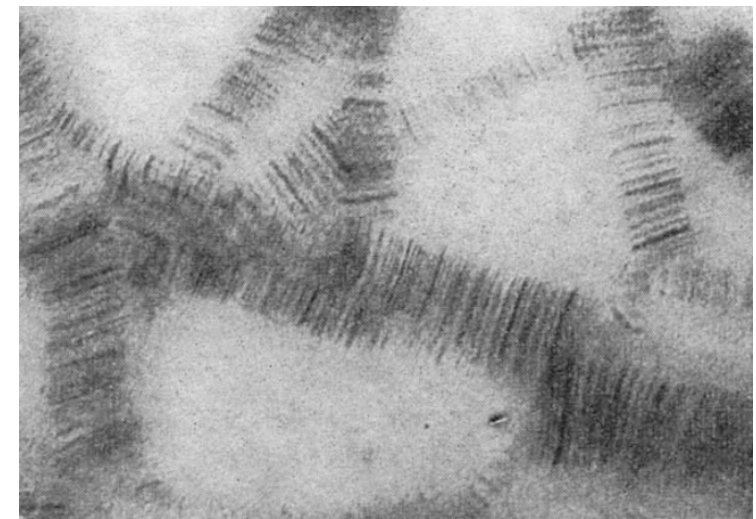

Fig. 2. Long-spacing segments from renatured al sub-units, produced by dialysis of the pepsin-treated solution in 0.05 per cent acetic acid against $0 \cdot 4$ per cent ATP solution, $p \mathrm{H} 3 \cdot 5$; stained with phosphotungstic

almost 40 per cent of the starting material. The crossstriation pattern appeared to be the same with respect to the position of the individual cross-striations when compared with normal collagen. There appears to be some difference in the intensitios of the individual bands. An exact photometric evaluation of the cross-striation pattern remains to be done.

These preliminary experiments indicate that it is possible to build a native-like triple helix from three $\alpha$ l chains. The cross-striation pattern of the segments thus obtained from $\alpha$ I argues against the collagen model of Hodge ${ }^{6}$ in which the $\alpha 1$ chain would be built up from five identical sub-sub-units and the $\alpha 2$ chain from seven identical sub-sub-units. If this were the case, then the crossstriation pattern of the long-spacing segments formed from $\alpha 1$ should be divided into five equal periods. The fact that no repeating period at all is evident suggests that it is very unlikely that $\alpha 1$ is composed of several identical smaller sub-units.

This investigation was supported by the Deutsche Forschungsgemeinschaft.

KLAUS KÜHN Chrtstian Tkocz BODO ZTMMERMANN GUNDOLF BeIER

Max-Planck-Institut für Eiweiss- und Lederforschung. Munich, Germany.

1 Piez, K. A., Eigner, F. A, and Lewis, M. S., Biochemistry, 2, 58 (1963) a Kühn, K, and Zimmermann, B., Arch. Biochem. Biophys., 109, 534 (1965). ${ }^{3}$ Piez, K. A., and Carrillo, A. L., Biochemistry, 3, 908 (1964).

- Kühn, K., Engel, J., Zimmermann, B., and Grassmann, W., Arch. Biochem. Biophys., 105, 387 (1964). Beier, G., Engel, J., and Grassmann, W, Biophysiker-Tagung Wien, 14-16.9.1964, Tagungsbericht, p. 101. ${ }^{5}$ Hippel, P. H. v., and Wong, K. Y., Biochemistry, 2, 1399 (1963).

- Hodge, A. J., Proc. U.S. Nat. Acad. Sci., 51, 871 (1964). 